\title{
Effects of pasture species and irrigation on milk production over four summers in the Waikato
}

\author{
E.R. THOM ${ }^{1}$, V.T. BURGGRAAF, C.D. WAUGH and D.A. CLARK \\ Dexcel, Private Bag 3123, Hamilton \\ 1'errol.thom@dexcel.co.nz
}

\begin{abstract}
Milk production by Jersey cows grazing a common allowance of irrigated or non-irrigated pastures over four summers (1997-2000) is described. The pastures were: (1) high-endophyte perennial ryegrass-white clover (2) tall fescue, phalaris, cocksfoot, white clover, red clover (3) same as (2) plus paspalum (4) endophyte-free ryegrass, timothy, white clover, red clover and (5) existing high-endophyte ryegrass-white clover. Irrigation improved milksolids yield by $5 \%$ over 4 years, with inconsistent effects on milk composition, no effects on pasture in vitro digestibility and nitrogen content, and usually no effect on pasture botanical composition. In 1997, cows on (1) produced the lowest milksolid (MS) yields. Cows grazing ryegrass-white clover (1 and 5) produced less than those on tall fescue-based pastures (2 and 3) ( $0.74 \mathrm{vs} 0.86 \mathrm{~kg} \mathrm{MS} /$ cow/day) in 1998 , and the yields of cows on ryegrass/timothy-based pastures (4) were best $(0.96 \mathrm{~kg} \mathrm{MS} / \mathrm{cow} /$ day). The same trends in milksolids yield occurred in 1999, except for cows on (1) which were similar to (4). Cows on existing pasture often produced the lowest milksolid yields. Trends in milksolids production over the 4 years reflected trends in total clover (red + white) contents.
\end{abstract}

Keywords: cocksfoot, dairy cows, grazing, pasture quality, perennial ryegrass, persistence, phalaris, red clover, tall fescue, timothy, triple mix, volunteer ryegrass, white clover

\section{Introduction}

Variation in summer rainfall and high summer temperatures causes variability in the quantity and quality of feed supply from ryegrass-white clover pastures (Thom et al. 1998; Barker et al. 1998).

The potential of irrigation to improve pasture yield (Hopewell 1958, 1960), pasture quality and milk production (Hutton 1974; Thomson 1996), has been identified by large-scale trials in the Waikato. A feature of Hopewell's work, conducted under sheep and beef cattle grazing, was the highly variable pasture yield responses to irrigation in summer, ranging from +37 to
$+575 \%$ over 11 years, reflecting the presence of different pasture species and variations in summer rainfall. The data of Hutton (1974) and Thomson (1996) suggested an extra 64 to $160 \mathrm{~kg} \mathrm{MS} / \mathrm{ha}$ in response to irrigation was possible. In contrast to Hutton (1974), Thomson (1996) reported little effect of irrigation on the in vitro digestibility and nitrogen content of ryegrass-white clover pasture.

Use of drought-tolerant grasses such as tall fescue, phalaris and cocksfoot (Hainsworth et al. 1991; Moloney 1991) may also improve forage supply in summer. These grasses have been advocated as "triple mixes" with red and white clovers for the Waikato and Manawatu and with paspalum added for the warmer Northland region; while an endophyte-free ryegrasstimothy mixture with red and white clovers was suggested for Canterbury dairy farms.

This paper reports on a component trial where the effects of irrigation and pasture species mixture on pasture quality and milk production were examined over four summers in the Waikato. An earlier paper (Thom et al. 1998) summarised some data from the first 2 years.

\section{Materials and methods}

Detailed descriptions of the trial site, fertiliser regime, milk testing, grazing management, grass and clover seeding rates and establishment procedures, pasture chemical analyses and Argentine stem weevil control were given in Thom et al. (1998).

\section{Pasture treatments and design}

A $2 \times 5$ split plot factorial design with four blocks (reps) was used in which irrigation (+ or -) were the main plots with five pasture treatments randomly allocated as subplots within each main plot. Pasture treatments were: (1) new high-endophyte 'Grasslands Nui' perennial ryegrass with 'Grasslands Kopu' white clover as control (HER) - total seeding rate $25 \mathrm{~kg} / \mathrm{ha}$; (2) 'Grasslands Advance' tall fescue, 'Grasslands Maru' phalaris, 'Grasslands Kara' cocksfoot, with 'Grasslands Kopu', 'Grasslands Prestidge' and 'Aran' white clovers, and 'Grasslands Colenso' red clover (TM) - total seeding rate, $34 \mathrm{~kg} / \mathrm{ha}$; (3) same as (2) plus 'Grasslands Raki' paspalum (TMP) - total seeding rate, $29.5 \mathrm{~kg} /$ ha; (4) endophyte-free 'Grasslands Marsden' and 
'Grasslands Greenstone' hybrid ryegrasses, 'Grasslands Kahu' timothy, with 'Grasslands Kopu', 'Grasslands Demand' and 'Aran'white clover, and 'Grasslands Colenso' red clover (LER) - total seeding rate, $31 \mathrm{~kg}$ / ha and (5) existing high-endophyte ryegrass and white clover (EP), as another control. Seed mixtures were sown into a cultivated seedbed from 12-19 March 1996.

\section{Irrigation}

From November to May of each year, soil water contents were monitored every 1-3 weeks using a Time Domain Reflectometer with probes permanently installed to $15 \mathrm{~cm}$ depth.

Soil water content of the trial site at field capacity was about $52 \%$, and at plant wilting point it was $24 \%$. Irrigation was applied on average every 9 days (range 5-20 days) using a travelling gun irrigator, when soil moisture content was about $38 \%$ (50\% available water).

\section{Milk testing}

Milk yield and composition were measured twice during the uniformity periods ( 7 days-all cows grazed ryegrasswhite clover) and during the first 7 days on treatment pastures. This was followed by five daily tests on treatments. Testing was done in January-February 1997-2000.

\section{Grazing management}

Herds of 10 Jersey cows, balanced for age, current milk production and liveweight, were offered a common pasture allowance (30 kg DM/cow/day), calculated from the pre-grazing herbage mass (see below).

Grazing management 3 to 4 weeks before milk testing was aimed at removing excessive seed-head and increasing green leaf availability.

\section{Pasture measurements}

Herbage accumulation: Pre- and post-grazing herbage mass was estimated from 50-100 readings per paddock with a rising plate meter. Plate meter readings were regularly calibrated using 20 to 40 ground level cuts per treatment.

Botanical composition: Herbage was clipped to ground level at the start of each milk test period. Botanical composition was determined by dissection into component species, expressed as \% of DM.

Chemical composition: Herbage samples clipped to ground level from each paddock grazed during milk test periods were analysed for in vitro organic matter digestibility, nitrogen and other chemical components (Thom et al. 1998).
Statistical analysis: Pasture data were analysed using a Genstat 5 split plot analysis of variance model. Milk production and composition data were analysed by SAS 6.12 using the uniformity data in an analysis of covariance with the data from individual cows as replicates.

\section{Results}

\section{Climate and soil water content}

Above average summer (December-February) rainfall in 1995-96 provided adequate soil conditions for March 1996 sowing. The following four summers were drier than normal with only $72,82,73$ and $53 \%$ of the 10 year average rainfall $(241 \mathrm{~mm})$. Average soil water contents on non-irrigated paddocks often fell below plant wilting point in January, February and March, ranging from 14 to $19 \%$ over 4 years compared with 29 to $42 \%$ when irrigated.

Irrigation applied from November 1996 to April 1997, December 1997 to March 1998, November 1998 to March 1999, and October 1999 to April 2000 was $310,323,644$ and $424 \mathrm{~mm}$, respectively.

The first three summers were warm, with screen maximum temperatures above $25^{\circ} \mathrm{C}$ on 18,37 and 55 days, respectively. Summer 1999/2000 was cooler with only 6 days above $25^{\circ} \mathrm{C}$.

\section{Milk production and composition}

Irrigation: Irrigation increased milksolids yield (MS/ cow/day) by $4-10 \%$ from 1998 to 2000 , with no effect in 1997 (Table 1), and with similar effects on milk yield. However, effects of irrigation on milk fat $\%$ and protein $\%$ were inconsistent and small when averaged over 4 years.

Table $₫ 1$ Effect of irrigation on milksolids yield (kg MS/cow/day) for cows offered a common pasture allowance in Januaryl February 1997 and 1998, and January 1999 and 2000.

\begin{tabular}{lccl}
\hline & Irrigation & No Irrigation & \multicolumn{1}{c}{ SED } \\
\hline Milksolids & & & \\
1997 & 1.02 & 1.01 & $0.021^{\mathrm{NS}}$ \\
1998 & 0.85 & 0.82 & $0.015^{*}$ \\
1999 & 0.90 & 0.85 & $0.032^{* * *}$ \\
2000 & 1.14 & 1.04 & $0.018^{\text {** }}$ \\
\hline
\end{tabular}

NS = not significant; ${ }^{*}=\mathrm{P}<0.05 ;{ }^{* *}=\mathrm{P}<0.001$

Pasture species mixture: Effects of pasture species on MS yields (Table 2) and milk yields were similar. Cows on HER pastures produced the lowest yields of MS in 1997 and 1998 along with cows on EP pastures, but were amongst the highest producers in 1999 and 2000. In 1998, cows on LER pastures produced the 
most milk, and this advantage was maintained over all treatments except HER in 1999. Cows on triple mix pastures (TM and TMP) produced more milk than the cows on ryegrass dominant pastures (EP and HER) in 1998, a trend that continued in 1999 and 2000, but only when compared with EP. With the exception of 1997, cows on EP pastures consistently produced the lowest MS yields. Pasture species had little effect on milk composition except in 1998 when protein \% was higher for LER cows (3.83 vs $3.77 \%$ ), an effect that contributed to their higher MS yields.

\section{Botanical composition}

Ryegrass (EP, HER, LER): Ryegrass usually dominated herbage mass during milk test periods (Table 3). Effects of irrigation on the content of ryegrass were detected in February 1997 (42 vs 30\%, SED $=2.5^{*}$ ) and February 1998 ( 25 vs $\left.12 \%, \mathrm{SED}=3.9^{*}\right)$. The content of ryegrass in LER pastures was significantly lower than in EP and in HER during the 1998 and 1999 milk test periods.

Tall fescue (TM, TMP): Tall fescue content was highest in the first summer, declining to $<5 \%$ by January 2000 (Table 3), when volunteer ryegrass reached a high level in TM $(53 \%)$ and TMP (34\%). Ryegrass contamination was noted in Year 1 (Table 3). Irrigation did not influence tall fescue content.

Red clover (TM, TMP, LER): Red clover in LER and triple mix pastures peaked in January 1998. Red clover content in all pastures then declined rapidly to be $<5 \%$ in January 1999 and 2000 (Table 3). Irrigation did not improve overall red clover content.

White clover (EP, HER, LER, TM, TMP): EP pastures had the highest white clover content (14\%) compared with an average of $4 \%$ or less in establishing pastures. Thereafter white clover in EP pastures was $<7 \%$, but reached about $20 \%$ in HER and LER in January 1999 , compared with $8 \%$ in triple mix pastures (Table 3). White clover content did not respond to irrigation.

Other sown species (TM, TMP, LER): Phalaris content of triple mix pastures averaged 5, 8, 8 and $14 \%$ over the 4 test periods, compared with cocksfoot contents of 18 , 24, 25 and $12 \%$, respectively. Phalaris and cocksfoot contents were not increased by irrigation. Timothy content in LER increased to about $15 \%$ in January 1998 and 1999 , but was $<5 \%$ in January 2000 . Irrigation did not affect timothy content during milk test periods. Paspalum failed to establish in TMP pastures.

Dead herbage (all pastures): During summer, the content of dead material was higher in the ryegrass-
Table $\llbracket 2$ Effect of pasture species mixture on milksolids yield ( $\mathrm{kg}$ MS/cow/day) in January/February 1997 and 1998, and January 1999 and 2000.

\begin{tabular}{lcccccc}
\hline & EP & HER & TM & TMP & LER & SED \\
\hline Milksolids & & & & & & \\
1997 & 1.05 & 0.96 & 1.00 & 1.05 & 1.01 & $0.03^{*}$ \\
1998 & 0.71 & 0.76 & 0.83 & 0.89 & 0.96 & $0.03^{*}$ \\
1999 & 0.81 & 0.91 & 0.85 & 0.85 & 0.94 & $0.02^{* * *}$ \\
2000 & 1.05 & 1.11 & 1.13 & 1.09 & 1.08 & $0.02^{*}$ \\
\hline
\end{tabular}

${ }^{*}=\mathrm{P}<0.05 ;{ }^{* * *}=\mathrm{P}<0.001$

${ }^{a} \mathrm{EP}=$ existing high-endophyte ryegrass-white clover; HER = highendophyte ryegrass-white clover; $\mathrm{TM}=$ tall fescue, phalaris, cocksfoot, white clover, red clover; TMP = tall fescue, phalaris, cocksfoot, paspalum, white clover, red clover; LER = endophyte-free ryegrass, timothy, white clover, red clover.

Table $\sqrt{3}$ Main component species (\% of DM) in different pasture mixtures during January-February milk test periods over 4 years.

\begin{tabular}{|c|c|c|c|c|c|c|}
\hline & -----. & EP & $\begin{array}{l}\text { Pastur } \\
\text { HER }\end{array}$ & $\begin{array}{l}\text { e mixture } \\
\text { TM/TMP }\end{array}$ & LER & SED \\
\hline \multirow[t]{4}{*}{1997} & $\mathrm{RG}^{\mathrm{c}}$ & 57 & 79 & 18 & 66 & $5.0^{* * *}$ \\
\hline & $\mathrm{TF}$ & - & - & 27 & - & - \\
\hline & $\mathrm{RC}$ & - & - & 10 & 7 & $4.1^{\mathrm{NS}}$ \\
\hline & WC & 14 & $<1$ & 4 & 1 & $1.9^{* *}$ \\
\hline \multirow[t]{4}{*}{1998} & RG & 60 & 53 & 13 & 27 & $5.9^{* * *}$ \\
\hline & $\mathrm{TF}$ & - & - & 16 & - & - \\
\hline & $\mathrm{RC}$ & - & - & 23 & 34 & $5.1^{*}$ \\
\hline & WC & 4 & 8 & 4 & 7 & $2.5^{\mathrm{NS}}$ \\
\hline \multirow[t]{4}{*}{1999} & RG & 43 & 28 & 8 & 19 & $5.8^{* * *}$ \\
\hline & TF & - & - & 13 & - & - \\
\hline & $\mathrm{RC}$ & - & - & 4 & 4 & $2.4^{\mathrm{NS}}$ \\
\hline & WC & 7 & 21 & 8 & 20 & $3.7^{* * *}$ \\
\hline \multirow[t]{4}{*}{2000} & RG & 56 & 53 & 43 & 48 & $6.8^{\mathrm{NS}}$ \\
\hline & TF & - & - & 2 & - & - \\
\hline & $\mathrm{RC}$ & - & - & 2 & $<1$ & $1.0^{\mathrm{NS}}$ \\
\hline & WC & 3 & 13 & 9 & 6 & $3.8^{\dagger}$ \\
\hline
\end{tabular}

a See Table 2 ; ${ }^{\mathrm{b}}$ average for $\mathrm{TM}$ and TMP pastures; ${ }^{\mathrm{c}} \mathrm{RG}=$ ryegrass; $\mathrm{TF}=$ tall fescue; $\mathrm{RC}=$ red clover; $\mathrm{WC}=$ white clover. $\mathrm{NS}=$ not significant; ${ }^{\dagger}=$ $\mathrm{P}<0.1 ;{ }^{*}=\mathrm{P}<0.05 ;{ }^{* *}=\mathrm{P}<0.01$;

$* * *=\mathrm{P}<0.001$.

based (EP, HER, LER) than in the triple mix pastures (TM, TMP). In January 1998, irrigation reduced dead material ( 8 vs $14 \%, \mathrm{SED}=1.1)$, especially in EP (11 vs $22 \%$ ) and HER (12 vs 24\%) pastures. Contents of dead material in EP and HER in January 1999 were similar to 1998 , causing another pasture $\mathrm{x}$ irrigation interaction.

\section{Seasonal herbage accumulation}

Irrigation: Irrigation consistently improved herbage production in summer. Irrigated paddocks produced 1030 to $1790 \mathrm{~kg} / \mathrm{ha}$ more dry matter in summer than unirrigated paddocks (Table 4). Averaged over 4 years, irrigated paddocks produced $20 \%$ more total dry matter than unirrigated paddocks, or an extra $1700 \mathrm{~kg} \mathrm{DM} / \mathrm{ha}$. 
Table $\llbracket 4$ Effect of irrigation on seasonal herbage accumulation (kg DM/ha) over 4 years.

\begin{tabular}{lrrl}
\hline Season & Irrigation & No Irrigation & SED \\
\hline Spring 1996 & 970 & 820 & $184^{\mathrm{NS}}$ \\
Summer 1996/97 & 4670 & 3020 & $620^{\dagger}$ \\
Autumn 1997 & 1660 & 1700 & $169^{\mathrm{NS}}$ \\
Total Year 1 & 7300 & 5540 & $423^{\mathrm{NS}}$ \\
Winter 1997 & 1310 & 1470 & $232^{\mathrm{NS}}$ \\
Spring 1997 & 3160 & 3380 & $52^{*}$ \\
Summer 1997/98 & 4060 & 3030 & $299^{*}$ \\
Autumn 1998 & 2320 & 2390 & $280^{\mathrm{NS}}$ \\
Total Year 2 & 10850 & 10720 & $474^{\mathrm{NS}}$ \\
Winter 1998 & 1620 & 1480 & $182^{\mathrm{NS}}$ \\
Spring 1998 & 2840 & 3060 & $135^{\mathrm{NS}}$ \\
Summer 1998/99 & 4050 & 2260 & $173^{* *}$ \\
Autumn 1999 & 2410 & 1590 & $168^{*}$ \\
Total Year 3 & 10920 & 8390 & $365^{\star *}$ \\
Winter 1999 & 2050 & 2040 & $336^{\mathrm{NS}}$ \\
Spring 1999 & 3890 & 3890 & $239^{\mathrm{NS}}$ \\
Summer 1999/2000 & 4610 & 3510 & $407^{\dagger}$ \\
Autumn 2000 & 1510 & 590 & $250^{*}$ \\
Total Year 4 & 12060 & 10030 & $793^{\dagger}$ \\
\hline
\end{tabular}

$\mathrm{NS}=$ not significant; $\dagger=\mathrm{P}<0.1 ;{ }^{*}=\mathrm{P}<0.05 ;{ }^{*}=\mathrm{P}<0.01$

${ }^{a}$ data from November only (30 days)

Pasture species mixture: HER pastures had lower herbage accumulation than other pastures from November 1996 to May 1997 (4780 vs $6290 \mathrm{~kg} \mathrm{DM/}$ ha, $\mathrm{SED}=423^{* * *}$ ), mainly owing to lower summer herbage accumulation (2520 vs $4340 \mathrm{~kg} \mathrm{DM} / \mathrm{ha}$, $\left.\mathrm{SED}=283^{* * *}\right)$. This trend was repeated in $1997 / 98$, but not in 1998/1999 or 1999/2000. There were few significant interactions between pasture type and irrigation treatments.

\section{Pasture digestibility and chemical composition}

Irrigation: Irrigation usually had no effect on pasture quality parameters. However, the average $\mathrm{P} \%$ in irrigated pastures over 4 years, regardless of species mixture, was always higher $(0.33 \%)$ than in unirrigated pastures $(0.27 \%)$, reaching significance $(\mathrm{P}<0.05)$ in three out of 4 years.

Pasture species mixture: Pasture species had a large effect on quality parameters (Table 5). EP and HER pastures had low $\mathrm{N}$ contents in 1998, as did EP and triple mix pastures in 1999 (averaging 2.3\% N or $14.4 \%$ crude protein).

\section{Discussion}

There have been few studies of the effects of irrigation and pasture species mixture on milk production. Some short-term and farmlet experiments using different pasture species have been conducted in Taranaki (Johnson \& Thomson 1996; Hainsworth \& Thomson
Table $₫ 5$ Effect of pasture species mixture on in vitro organic matter digestibility (IVD) and nitrogen (N) (\% of DM) in whole pasture in January of 1997, 1998, 1999 and 2000.

\begin{tabular}{cccccccc}
\hline & & & & & & \\
& & EP & HER & TM & TMP & LER & SED \\
\hline IVD & 1997 & 72 & 76 & 69 & 70 & 72 & $1.0^{* * *}$ \\
& 1998 & 66 & 68 & 66 & 65 & 69 & $3.0^{\text {NS }}$ \\
& 1999 & 65 & 66 & 65 & 65 & 65 & $1.4^{\text {NS }}$ \\
& 2000 & 74 & 75 & 74 & 73 & 73 & $1.7^{\text {NS }}$ \\
& 1997 & 2.7 & 2.6 & 2.8 & 2.7 & 2.7 & $0.15^{\text {NS }}$ \\
& 1998 & 1.9 & 2.3 & 2.5 & 2.4 & 2.7 & $0.14^{* * *}$ \\
& 1999 & 2.1 & 2.7 & 2.3 & 2.3 & 2.6 & $0.11^{\text {*** }}$ \\
& 2000 & 2.6 & 2.8 & 2.8 & 2.7 & 2.7 & $0.11^{\text {NS }}$ \\
\hline
\end{tabular}

NS $=$ not significant; ${ }^{* * *}=P<0.001$.

a See Table 2.

1997), and in the Waikato (Exton et al. 1996), under dryland conditions. In the Taranaki and the current trial, the different pastures were fed at common allowances, so that any effects were likely to be caused by differences in herbage composition (or quality) not by quantity offered. Herbage mass during milk test periods in the current trial was at least $2500 \mathrm{~kg} \mathrm{DM} / \mathrm{ha}$, and was unlikely to restrict cow intake (Holmes 1987).

This component trial examined how different pasture species combinations and irrigation affected pasture quality as measured by milksolids responses from the cows grazing the pastures. To avoid introducing grazing interval as another variable, all pastures were grazed at about the same time leading up to and during the milk test periods. This constraint, however, often resulted in high pre-grazing yields, especially on tall fescue-based pastures, that could have reduced pasture quality. Furthermore, these yields sometimes exceeded the upper limit ( $4000 \mathrm{~kg} \mathrm{DM} / \mathrm{ha})$ when the estimates made by the rising plate meter could be unreliable (Lile et al. 2001). These constraints must be borne in mind when interpreting the data.

\section{Effects of irrigation on milk production}

Small milksolids responses to irrigation (averaging $5 \%$ over 4 years, Table 1) reflected inconsistent effects on milk fat and protein \%, and no effect of irrigation on digestibility or most of the chemical components of the pasture, confirming the results of Thomson (1996). The content of many pasture species (ryegrass, tall fescue, white clover, red clover, cocksfoot, phalaris, timothy) was not changed by irrigation. Thomson (1996) reported similar irrigation responses over 2 years for perennial ryegrass and white clover.

It is difficult to pinpoint why cows grazing irrigated pastures tended to produce more milksolids as the trial proceeded, although, reductions in dead herbage in irrigated pastures in January 1998 and 1999 could 
have increased the quality of cow intake and therefore milksolids yield (Hoogendoorn et al. 1992). If irrigation increased the green leaf proportion of the $30 \mathrm{~kg} \mathrm{DM} /$ day cow allowance this would have increased cow intake of green leaf and therefore metabolisable energy (Butler et al. 1987) compared with the cows on unirrigated pastures. Like Thomson (1996), we also found irrigation promoted $\mathrm{P}$ uptake in pasture plants. Low $\mathrm{P}$ levels (averaging $0.27 \%$ of $\mathrm{DM}$ ) were present in unirrigated pastures during milk test periods. Although irrigation consistently increased these levels to $0.33 \%$, they were still below $0.40 \%$, the level necessary to sustain high milk production (Thomson 1996).

\section{Effects of pasture species on milk production}

A comparison of data for years 1-4 in Tables 2 and 3 shows that the cows on the treatments producing the most milksolids were those containing the most clover. Many reports (e.g., Harris et al. 1997; O’Brien \& Vermazen 1989) have shown the importance of high clover contents to the nutritive value or quality of the cow's diet.

Cows on EP pastures containing 14\% white clover in January 1997 produced $9 \%$ more MS than cows on HER containing $<1 \%$ white clover. Red clover dominated the legume content of LER and triple mix pastures by January 1998 , with $41 \%$ total legume in the former and $27 \%$ in the latter, compared with an average of only $6 \%$ white clover in HER and EP pastures, again mirroring milk production trends (Table 2). At the same time, LER pastures contained near peak levels of timothy (15\%), while triple mix pastures had cocksfoot and tall fescue contents of $24 \%$ and 16\%, respectively. Johnson \& Thomson (1996) showed the benefits of timothy over cocksfoot in relation to milk production, and that cocksfoot was associated with a lower protein \%, supporting our results (Table 2).

Red clover lasted 2 years before declining, probably reflecting attack by root pathogens and competition from ryegrass (Hay \& Ryan 1989). In contrast, white clover proliferated in LER and HER, averaging $20 \%$ by January 1999, once again matching the milksolids production trends (Table 2). Milksolids production trends were less clear-cut in January 2000, but were still highest for treatments with the highest clover contents.

Pasture digestibility (Table 5), a major determinant of pasture quality (Holmes 1987), did not reflect the peak pasture clover contents in some treatments in 1998 and 1999 (Table 3). Harris et al. (1997) showed that as pasture clover content increased from zero (pure ryegrass) to $50 \%$, in vitro digestibility increased from 64 to $71 \%$. In our trial, digestibility analyses were done on whole pasture samples, which may not represent the herbage that was selected by the cows. The grazing management did not completely control the growth of the less digestible grass stem material. This probably reduced the effect of high clover content on the digestibility estimates. It is likely that selection of a higher quality diet by the cows occurred (e.g., clover, green leaf) (Holmes 1987), accounting for the milksolids responses measured.

Low nitrogen contents in EP and HER in 1998 and EP pastures in 1999 (Table 5), equivalent to $12-14 \%$ crude protein, could have limited milksolids' production. About $2.6 \% \mathrm{~N}$ or a crude protein content of $16 \%$ is considered adequate to meet cow requirements in mid-lactation (Thomson 1996), so levels of 2.3 and $2.5 \% \mathrm{~N}$ in TM and TMP pastures in 1998 and 1999, were also marginal.

Milksolids production from triple mix pastures in January 2000 largely reflected responses to volunteer ryegrass $(43 \%)$, with low contents of tall fescue $(2 \%)$, phalaris $(14 \%)$ cocksfoot $(12 \%)$, white clover $(9 \%)$ and red clover (2\%). Rapid contamination of endophytefree perennial ryegrass-based pastures can occur (Thom et al. 1999a). The early contamination of pastures sown with endophyte-free grasses (TM, TMP and LER) reduced the possibility of differential treatment effects owing to endophyte. Nevertheless, we have not shown large effects of endophyte on milk production (Thom et al. 1999b).

\section{Impact of irrigation in the Waikato}

Large scale irrigation trials under cattle grazing in the Waikato have previously been conducted over 11 years by Hopewell (1960), and over 2 years by Hutton (1974) and Thomson (1996). Hopewell (1960) reported the largest average summer responses to irrigation (6330 vs $3130 \mathrm{~kg} \mathrm{DM} / \mathrm{ha}$ ) possibly reflecting the presence of $\mathrm{C}_{4}$ grass species.

Assuming a response of $70 \mathrm{~g} \mathrm{MS} / \mathrm{kg} \mathrm{DM}$ (N.A. Thomson, pers. comm.), the extra $1700 \mathrm{~kg} \mathrm{DM} / \mathrm{ha}$ produced on average over 4 years in response to irrigation, would be equivalent to an extra $119 \mathrm{~kg} \mathrm{MS} /$ ha. This result falls within the range of 64 to $160 \mathrm{~kg}$ MS/ha reported by Thomson (1996) for ryegrass-white clover pastures, and for Hutton (1974) who reported an extra $100 \mathrm{~kg} / \mathrm{ha}$ of milk fat or $160 \mathrm{~kg} \mathrm{MS} / \mathrm{ha}$ from irrigated pastures. These data provide a starting point to assess the potential of irrigation as a possible option for increasing profitability on individual farms.

\section{Conclusions}

Over four dry summers, the overall effects of irrigation on pasture quality were small. Cows on irrigated pastures averaged $5 \%$ higher yields of milksolids than 
the cows on unirrigated pastures, reflecting little change in the pasture quality indicators like in vitro digestibility and nitrogen content in response to irrigation.

Pasture species had a strong influence on milksolids yield. Total clover content (white + red clover) was strongly related to milk production trends. Triple mix pastures became dominated by volunteer ryegrass. Irrigation did not modify these trends.

Milk production from irrigated pastures is more likely to depend on the quantity of extra dry matter produced rather than on large improvements in pasture quality.

\section{ACKNOWLEDGEMENTS}

Helen Simons, Roslyn Watts and Elizabeth Grayling provided technical assistance; Michael Bennenbroek assisted with the establishment of pastures; Pat Laboyrie, Dave Wildermoth and Erna Jansen for grazing management and irrigation requirements; Rhonda Hooper and Barbara Dow for statistical analysis; Alec McGowan (AgResearch) for maintaining the TDR; the Foundation for Research Science and Technology for funding.

\section{REFERENCES}

Barker, D.J.; Clark, D.A.; Thom, E.R.; Couchman, J.; Burton, R.; Dymock, N. 1998. Pasture species and drought impact on milk yield 2. Predicted milk yield at four sites. Proceedings of the New Zealand Grassland Association 60: 45-50.

Butler, B.M.; Hoogendoorn, C.J.; Richardson, M.A. 1987. The influence of leaf allowance on animal performance in late spring and summer. Proceedings of the $4^{\text {th }}$ Animal Science Congress of the Asian-Australasian Association of Animal Production, Hamilton, New Zealand. p. 174.

Exton, P.R.; Dawson, J.E.; Thomson, N.A.; Moloney, S. 1996. More summer milk - progress to date. Proceedings of the Ruakura Dairy Farmers' Conference 48: 34-41.

Hainsworth, R.J.; Thomson, N.A. 1997. Milk production from different pastures: Taranaki experience. Dairyfarming Annual 49: 134-141.

Hainsworth, R.J.; Thomson, N.A.; McCallum, D.A.; Judd, T.G. 1991. Evaluation of dryland species and new ryegrass cultivars to increase pasture productivity in coastal Taranaki. Proceedings of the New Zealand Grassland Association 53: 5558.

Harris, S.L.; Clark, D.A.; Auldist, M.J.; Waugh, C.D.; Laboyrie, P.G. 1997. Optimum white clover content for dairy pastures. Proceedings of the New Zealand Grassland Association 59: 29-33.
Hay, R.J.M.; Ryan, D.L. 1989. A review of 10 years' research with red clovers under grazing in Southland. Proceedings of the New Zealand Grassland Association 50: 181-187.

Holmes, C. W. 1987. Pastures for dairy cows. pp. 133-143. In: Livestock Feeding on Pasture. Ed. Nicol, A.M. New Zealand Society of Animal Production, Occasional Publication No. 10.

Hoogendoorn, C.J.; Holmes, C.W.; Chu, A.C.P. 1992. Some effects of herbage composition, as influenced by previous management, on milk production by cows grazing on ryegrass-white clover pastures. 2 . Milk production in late spring-summer: effects of grazing intensity during the preceding spring period. Grass and Forage Science 47: 316-325.

Hopewell, H.G. 1958. Sprinkler irrigation of pastures in the North Island. New Zealand Journal of Agriculture 96: 106-110.

Hopewell, H.G. 1960. Spray irrigation. New Zealand Journal of Agriculture 100: 77.

Hutton, J.B. 1974. The effect of irrigation on forage yield, dairy cow production and intake under intensive grazing conditions in New Zealand. Proceedings of the $19^{\text {th }}$ Dairy Congress, New Delhi, 1E: 73-74.

Johnson, R.J.; Thomson, N.A. 1996. Effect of pasture species on milk yield and milk composition. Proceedings of the New Zealand Grassland Association 57: 151-156.

Lile, J.A.; Blackwell, M.B.; Thomson, N.A.; Penno, J.W.; Macdonald, K.A.; Nicholas, P.K.; Lancaster, J.A.S. 2001. Practical use of the rising plate meter (RPM) on New Zealand dairy farms. Proceedings of the New Zealand Grassland Association 63: 159164.

Moloney, S.C. 1991. Performance of tall fescue, cocksfoot and phalaris based pastures compared with perennial ryegrass, in on farm trials. Proceedings of the New Zealand Grassland Association 53: 41-46.

O’Brien, G.; Vermazen, R. 1989. A comparison between dairy cows productivity on 'high' clover and existing pasture systems. Dairy production research report, Dairy Research Institute, Ellinbank, Victoria, Australia.

Thom, E.R.; Clark, D.A.; van Vught, V.T.; Waugh, C.D. 1998. Pasture species and drought impact on milk yield 1. Milk yield responses in the Waikato. Proceedings of the New Zealand Grassland Association 60: 39-44.

Thom, E.R.; Clark, D.A.; Waugh, C.D. 1999a. Growth, persistence, and alkaloid levels of endophyte-free ryegrass pastures grazed by dairy cows in northern New Zealand. New Zealand Journal of Agricultural Research 42: 241-253. 
Thom, E.R.; Clark, D.A.; Waugh, C.D. 1999b. Endophyte and dairy production in New Zealand: experience at the Dairying Research Corporation. Ryegrass endophyte: an essential New Zealand symbiosis. Grassland Research and Practice Series 7: 39-44.

Thomson, N.A. 1996. Irrigation and pasture quality. Proceedings of the Ruakura Farmers' Conference 48: 58-66. 